\title{
Interaction of higher plant ribosomal 5S RNAs with Xenopus laevis transcriptional factor IIIA
}

\author{
Mirosława Z. Barciszewska \\ Institute of Bioorganic Chemistry of the Polish Academy of Sciences, Z. Noskowskiego 12, \\ 61-704 Poznań, Poland
}

Received 25 June, 1993

Key words: Xenopus laevis transcriptional factor IIIA, plant 5 S rRNAs, protein-nucieic acid interaction

\begin{abstract}
In this paper transcriptional factor IIIA (TFIIIA) has been used as a probe for identity of three-dimensional-structure of eukaryotic 5S rRNAs. I was interested in finding a common motif in plant and Xenopus 5S rRNAs for TFIIIA recognition. I found that the two eukaryotic 5S rRNAs (from wheat germ and lupin seeds) are recognized by $X$. laevis TFIIIA and the data clearly suggest that these $5 \mathrm{~S}$ rRNAs have very similar if not identical three-dimensional structures. Also effects of various conditions on stability of these complexes have been studied.
\end{abstract}

Transcriptional factor IIIA (TFIIIA) ${ }^{1}$ is one of several protein factors necessary for regulation of transcription of the $5 S$ ribosomal RNA genes in Xenopus laevis oocytes [1,2]. TFIIIA is a 40 $\mathrm{kDa}$ protein which specifically binds the $5 \mathrm{~S}$ rRNA gene during oogenesis and, in the presence of two additional factors, promotes transcription by RNA polymerase III. In the immature oocytes TFIIIA also binds to the $5 S$ rRNA forming a $7 \mathrm{~S}$ ribonucleoprotein particle (RNP) which stores the 5S rRNA required for ribosome assembly [3-9]. Since TFIIIA interacts with both types of nucleic acids, one can suggest that it interacts either with an A-form of DNA or of RNA. Recently a model for interaction of zinc fingers of TFIIIA in the major groove of B-DNA through an alpha helix [1014] has been proposed. The TFIIIA-DNA binding properties are well understood [14], but RNA binding properties of TFIIIA are much less known. The formation of the TFIIIA-5S rRNA complex (7S RNP) of Xenopus laevis oocytes has been studied by various kineticand other methods $[15,16]$ and a protein binding domain was localized within helix II/loop B and helix IV/loop E of a cognate $5 S$ rRNA molecule [17-20]. On the other hand, exogenous $5 S$ rRNAs from Escherichia coli, Rattus rattus, Thermoplasma acidophilum, Equisetum arvense inhibit transcription of the Xenopus 5S rRNA gene [21, 22]. From those studies it has been concluded, that the universally conserved $5 S$ rRNA structural elements, but not nucleotide sequence, are important in the interaction of 5 S rRNA with TFIIIA.

The replacement of the cognate by an eubacterial 5S rRNA in a $7 \mathrm{~S}$ particle shows that TF IIIA is capable of recognizing $5 S$ rRNA structure in general. Recently, the three-dimensional structure model of Xenopus laevis 5S rRNA, of distorted Y-shape, has been proposed $[4,20]$. The authors suggest that Xenopus TFIIIA interacts primarily with the helix II/loop B and helix IV/loop E/helix V domains [15, 16], and recognized mainly the structural features of which the predominant is the elongated and

\footnotetext{
${ }^{1}$ Abbreviations: BB, bromophenol blue; BSA, bovine serum albumin; DTT, dithiothreitol; RNP, ribonucleoprotein particle; TFIIIA, transcriptional factor IIIA; Xl, Xenopus laevis.
} 
bent helical 5S RNA structure formed by the nearly collinear stacking of helices II and V [18, 19].

Recently, on the basis of various biochemical, chemical and physico-chemical studies, a new model of the secondary and tertiary structure of plant $5 S$ rRNAs has been proposed [7], in which tertiary interactions exist between the loops B, C and E, D, respectively $[23,24]$. This model is quite different from the proposed $Y$ shape model [4].

The aim of this work was to use Xenopus TFIIIA as a probe for testing the similarity (identity) or difference of the structure of plant and Xenopus 5S RNAs. It would be very interesting to study the interaction of plant $5 \mathrm{~S}$ rRNA with a plant TFIIIA-like transcriptional factor, however, such a protein so far has not been found in plants. Therefore I decided to check the interaction of plant $5 S$ rRNAs with $X$. laevis TFIIIA. The $7 \mathrm{~S}$ complex formation suggested that the two $5 S$ rRNAs, from frog and plants have a very similar tertiary structure, despite that in either case a different three-dimensional model has been proposed [6, 7].

\section{MATERIALS AND METHODS}

Preparation of X. laevis transcriptional factor. The 7S RNP particle was obtained essentially as described previously [25]. Then the precipitate was resolubilized in buffer A [25] and TFIIIA precipitated with an equal volume of saturated ammonium sulphate, while $5 S$ rRNA remain in the supernatant. The protein was finally purified on a Bio-Rex 70 (BioRad) column. The TFIIIA precipitate was dissolved in buffer $\mathrm{H}$ ( $50 \mathrm{mM}$ Hepes, pH 7.5, $5 \mathrm{mM}$ $\mathrm{MgCl}_{2}, 1 \mathrm{mM}$ dithiothreitol, DTT, $20 \mu \mathrm{MZnCl}_{2}$, $0.5 \mathrm{mM}$ benzamidine, $2 \mu \mathrm{g} / \mathrm{ml}$ leupeptin ( $\mathrm{BDH}$ Chemicals), $2 \mu \mathrm{g} / \mathrm{ml}$ aprotinin (BDH Chemicals) and applied to the $0.2 \mathrm{ml}$ Bio-Rex $70 \mathrm{col}$ umn pre-equilibrated in buffer $\mathrm{H}$. After washing the column with the same buffer, bound protein was eluted with $1 \mathrm{M} \mathrm{KCl}$ in buffer $\mathrm{H}$. Using a Bio-Rex column for separation of the protein from $5 S$ rRNA, I omitted RNase A treatment step. Protein fraction samples were made in $25 \mathrm{mM}$ Tris/ $\mathrm{HCl}, \mathrm{pH} 6.8$, $0.5 \%$ SDS, $5 \%$ glycerol, $0.05 \%$ bromophenol blue (BB), $0.5 \%$ 2-mercaptoethanol and analysed in $12 \%$ SDS-polyacrylamide gels. The fractions 4-8 from the Bio-Rex 70 column were used for the further studies.

Formation of the complex of plant $5 S$ rRNA with Xenopus TFIIA by exchange reaction. The reaction was carried out in a total volume of $10 \mu \mathrm{l}$ at $20^{\circ} \mathrm{C}$ for $2 \mathrm{~h}$ in buffer $1(20 \mathrm{mM}$ Tris/ $\mathrm{HCl}$, pH 7.5, $5 \mathrm{mM} \mathrm{MgCl}, 100 \mathrm{mM} \mathrm{KCl}$, $100 \mu \mathrm{g} / \mathrm{ml}$ bovine serum albumin, BSA, $1 \mathrm{mM}$ DTT) or buffer $2(50 \mathrm{mM}$ Tris/ $\mathrm{HCl}, \mathrm{pH} 7.5,3$ $\mathrm{mM}$ DTT, $15 \mu \mathrm{g} / \mathrm{mlBSA}$ ). The concentration of a stock solution of 7S RNP was $8.7 \mu \mathrm{M}$. Prior to the reaction plant $5 \mathrm{~S} \mathrm{rRNAs}$ were renatured in $50 \mathrm{mM}$ Tris/ $\mathrm{HCl}$ buffer, $\mathrm{pH} 7.6$, containing 1 $\mathrm{mM} \mathrm{MgCl} 2$ and $25 \mathrm{mM} \mathrm{KCl}$ by heating to $60^{\circ} \mathrm{C}$ followed by slow cooling. One nanomole (10000 c.p.m.) of $5 \mathrm{~S}$ rRNA was used for the reaction.

Theanalysis of the 7SRNP complex formation was carried out in $0.7 \%$ agarose gels. The samples were loaded on the gel in $4 \mathrm{mM}$ Tris $/ \mathrm{HCl}$, pH 7.4 with $4 \%$ glycerol and $0.02 \% \mathrm{BB}$ and run at $30 \mathrm{~mA}$ for $45 \mathrm{~min}$ (BB to the bottom of the gel) in $45 \mathrm{mM}$ Tris/boric acid, $\mathrm{pH} 8.3$.

Binding of plant $5 S$ rRNAs to $X$. laevis TFIIIA. Stock solution of TFIIIA used has concentration of $26.7 \mu \mathrm{M}$. Reactions were carried out in buffer 3 ( $20 \mathrm{mM}$ Tris $/ \mathrm{HCl}, \mathrm{pH} 7.4,70 \mathrm{mM}$ $\mathrm{KCl}, 20 \mu \mathrm{M}$ zinc acetate, $1 \mathrm{mM}$ DTT, $6 \%$ glycerol, $0.1 \%$ Nonidet $\mathrm{P}-40$ and $100 \mu \mathrm{g} / \mathrm{ml} \mathrm{BSA}$ ), or in buffer $4(50 \mathrm{mM}$ Tris/ $\mathrm{HCl}, \mathrm{pH} 7.5,3 \mathrm{mM}$ DTT, $15 \mu \mathrm{g} / \mathrm{ml} \mathrm{BSA}$ ). The analysis of $7 \mathrm{~S}$ complex formation was carried out on $0.7 \%$ agarose gel. One nanomole (10000 c.p.m.) of 5S rRNA was used for each reaction.

RNasin was from Serva. 5S rRNA from lupin seeds and wheat germ were purified as previously described [7]. Labeling of $5 S$ rRNA was done at $5^{\prime}$ or $3^{\prime}$ ends with $\left[\gamma^{32} \mathrm{P}\right] \mathrm{ATP}$, and T4 kinase or $\left[{ }^{32} \mathrm{P}\right] \mathrm{pC} \mathrm{P}$ and $\mathrm{T} 4$ ligase, respectively [23].

\section{RESULTS AND DISCUSSION}

The aim of this study was to show whether it is possible to obtain a complex between plant 5S rRNA and Xenopus laevis transcriptional factor IIIA (7S complex) and to test the effects of various conditions on its formation and stability. The final purity of TFIIIA was checked on SDS-polyacrylamide gel (Fig. 1).

I studied formation of the complex between Xentopus TFIIIA and 5S rRNA from plants by 


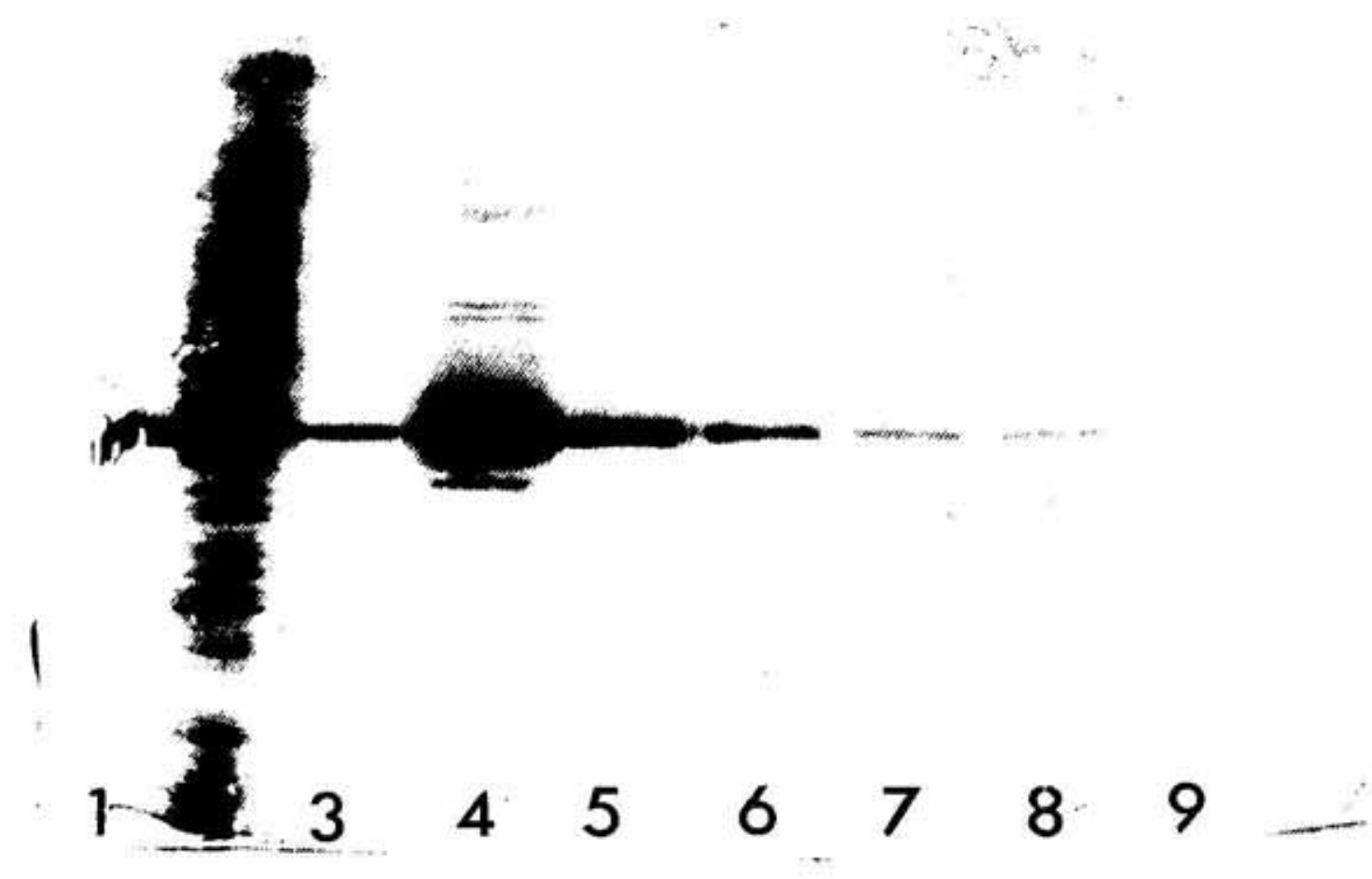

Fig. 1. Analysis of the purity of Xenopus laevis transcriptional factor (TFIIIA) on SDS-polyacrylamide gel, stained with Coomassie Brilliant Blue R-250.

Lanes: 1, Xenopus TFIIIA (size marker); 2, supernatant $40000 \times g ; 3-9$, successive protein fractions from the Bio-Rex 70 column.

two methods: a) an exchange reaction between plant $5 \mathrm{~S}$ rRNAs and Xenopus laevis (Xl) 5S rRNA in the 7S RNP complex, according to the scheme:

[5S rRNA (X1)-TPIIIA $(X 1)]+5 S$ rRNA (plant) $\rightarrow$ [5S rRNA (plant) -TFIIIA $(X 1)]+5 S \operatorname{rRNA}(X I)$

and $b$ ) by binding of plant $5 S$ rRNA to the free TFIIIA protein.

I found that a heterologous $7 \mathrm{~S}$ complex can be formed by the exchange reaction in buffer 2 at a higher rate than in the buffer 1 , and therefore the former buffer was used for further studies (Fig. 2). By varying concentrations of the reactants, I established optimum conditions in which lupin and wheat $5 S$ rRNAs were able to substitute Xenopus 5S rRNA involved in the 7S complex. The lowest concentrations of 7S RNP particle at which exchange reaction took place was $0.87 \mu \mathrm{M}$ (Fig. 2, lanes 3,9). The extent of the exchange reaction between two Xenopus $7 S$ RNP complex and plant $5 S$ rRNAs (Fig. 2) was different, but comparable to that, of Xenopus $5 \mathrm{~S}$ rRNA [26]. I interpreted these differences in terms of the RNA primary structure variations. Comparison of the nucleotide sequence $X$. laevis, E. coli [15] and plant $5 S$ rRNAs (Table 1) shows that the similarity was not very high and the sequences showed only about $60 \%$ homology. There are also substantial differences in association constants between TFIIIA and prokaryotic and eukaryotic 5S rRNAs [15], (Table 1). It is likely that despite these large differences in the nucleotide sequence, the tertiary structure of different $5 \mathrm{~S}$ rRNAs is very similar. One can also notice that, in addition to a strong band corresponding to 7S rRNP complex, there is a band for $5 S$ rRNA itself and some bands due to RNA degradation products (Fig. 2). It is known that RNasin inhibits mainly the RNase A activity [15], but I did not observe any significant reduction in the amount of the degradation products after RNasin addition. There is also a possibility that TFIIIA itself has some hydro- 


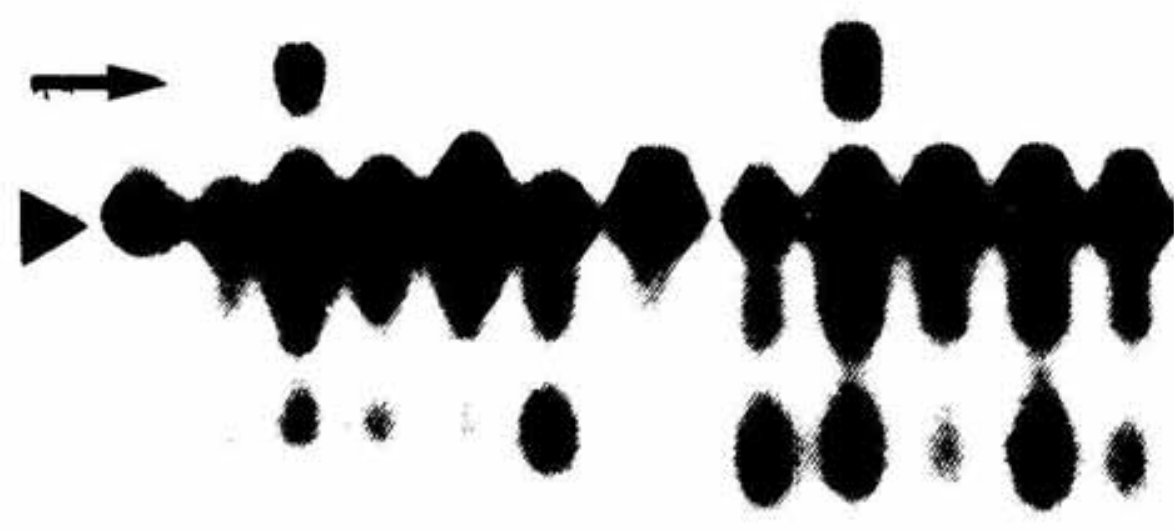

Fig. 2. Effects of different plant $5 S$ rRNAs (triangle) on the exchange reaction with Xenopus $7 S$ RNP complex (arrow) analysed on $0.7 \%$ agarose gel.

The reaction was run in buffer 2 containing $0.001 \mathrm{M} \mathrm{MgCl}_{2}$ and $0.15 \mathrm{M} \mathrm{KCl}$. Lanes 1 and $7:{ }^{32} \mathrm{P}$. labeled-5S rRNA of lupin and wheat, respectively; $2-6$ :lupin $5 S$ rRNA, and 8-12: wheat germ $5 S$ rRNA in the presence of varying amounts of 7S RNP; lanes 2, 8:

\section{$\begin{array}{llllllllllll}1 & 2 & 3 & 4 & 5 & 6 & 7 & 8 & 9 & 10 & 11 & 12\end{array}$}

$0.44 \mu \mathrm{M} ; 3,9: 0.87 \mu \mathrm{M} ; 4,5,10,11$ : $0.017 \mu \mathrm{M} ; 6,12: 0.034 \mu \mathrm{M}$. lytic properties. The heterologous complex TFIIIA $(X I)$-5S rRNA(plant) was stable over the temperature range $20-42^{\circ} \mathrm{C}$ up to $2 \mathrm{~h}$. Addition of zinc ions at a concentration exceeding $10 \mu \mathrm{M}$ precipitate a TFIIIA and the optimum magnesium concentration was below $1 \mathrm{mM}$.

The second method of the 7S RNP complex formation used was binding of plant $5 \mathrm{~S}$ rRNA to X. laevis TFIIIA itself [27]. The complex formation in buffer 3 which unlike buffer 4 , con- tained zincand potassium ions as well as glycerol and Nonidet, when supplemented with magnesium, was more effective (Fig. 3) than in buffer 4 (not shown). The presence of Nonidet in the binding buffer was necessary for stability of the 7S complex (Fig. 4). Low concentrations of zinc ions and glycerol had a very small effect (Fig. 4) but EDTA above $100 \mathrm{mM}$ destroyed the complex (Fig. 5). At magnesium concentration below $0.1 \mathrm{mM}$, the 7S RNP complex was ob-

Table 1

The nucleotide sequence homology in higher plants, E. coli and X. laevis $5 S r R N A s$ in formation of $7 S$ $R N P$ complex by the exchange reaction. The free energy $\Delta G$ of the $5 S r R N A$ s have been calculated by Zucker programme as described earlier $[28,29]$.

\begin{tabular}{|l|c|c|c|c|}
\hline Source of 5S rRNA & $\begin{array}{c}\text { Homology with } \\
\text { X. laevis 5S rRNA } \\
\%\end{array}$ & $\begin{array}{c}\text { Association } \\
\text { constant } \\
\mathrm{Ka}_{\mathrm{a}}\left(\mathrm{M}^{-1}\right)^{*}\end{array}$ & $\begin{array}{c}\Delta \mathrm{G} \\
(\mathrm{kcal} / \mathrm{mol})\end{array}$ & $\begin{array}{c}\text { Number of } \\
\text { different positions }\end{array}$ \\
\hline X. laevis & 100 & $1.0 \pm 0.5 \times 10^{9}$ & 38.6 & \\
\hline Wheat germ & 62.8 & $2.7 \pm 0.5 \times 10^{9}$ & 25.8 & 45 \\
\hline Lupin seeds & 59.5 & - & 31.8 & 49 \\
\hline E. coli & 27.2 & $2.5 \pm 1.0 \times 10^{8}$ & 37.6 & 88 \\
\hline
\end{tabular}

- Data taken from [15]. 


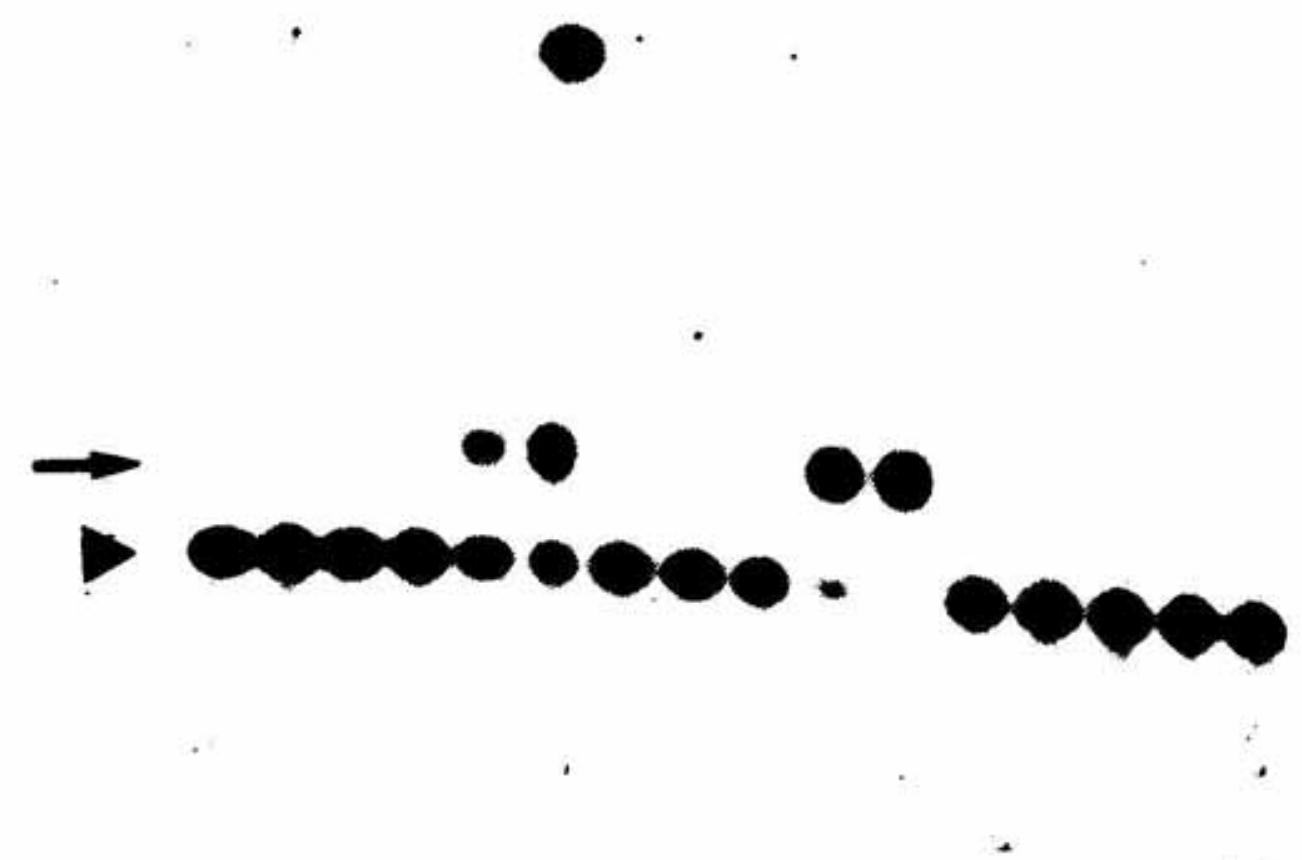

\section{6}

Fig. 3. Analysis of the binding of plant ${ }^{32}$ P-labeled-5S rRNAs (triangle) by X. laevis TFIIIA on $0.7 \%$ agarose gels.

Formation of the 7S RNP complex (arrow) was performed in buffer 3. Lanes: 1, 5S rRNA of lupin; 2-6, increasing TFIIIA to 5 rRNA ratio 1:1, 10:1, 20:1, 100:1 and 200:1, respectively, in the buffer containing $10 \mathrm{mM}$ magnesium; 7-11, the same as in 2-6 but without magnesium; 12-14, decreasing ratio of 5S rRNA to TFIIIA, 150:1, 100:1 and 50:1, respectively, in the buffer containing magnesium; $15-16$, the same as $12-13$ but without magnesium.
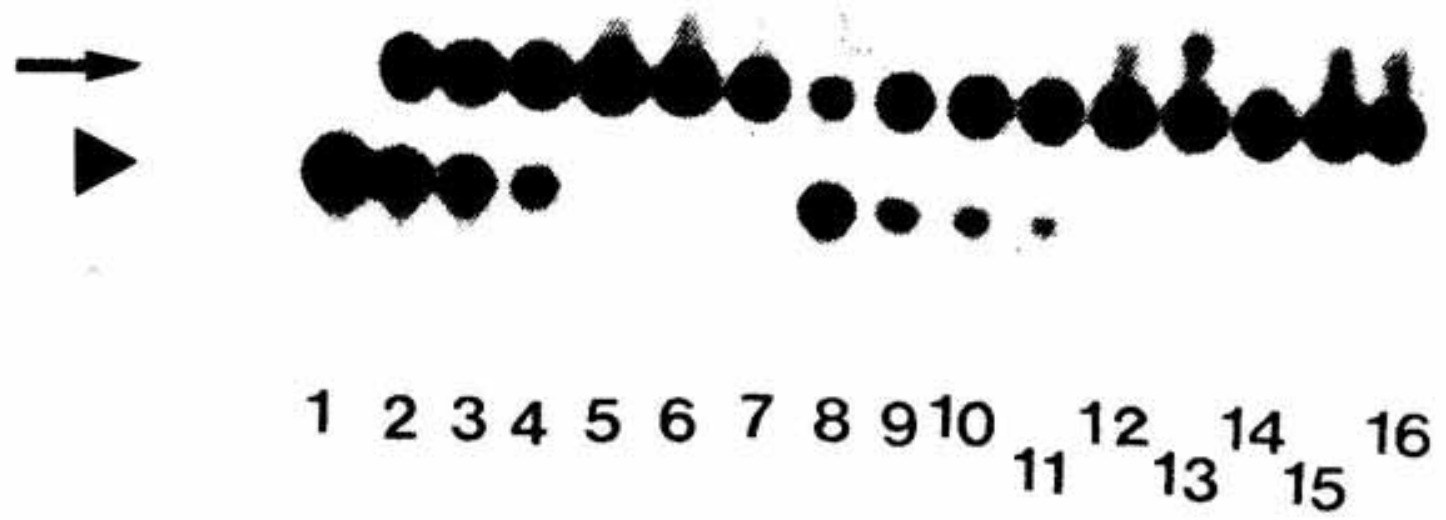

Fig. 4. The effects of RNasin, $\mathrm{Zn}^{2+}$ ions, glycerol and Nonidet $P-40$ on binding of lupin $5 S$ rRNA to Xenopus laevis TFIIIA.

Lanes: 1, 1 nmole $5 S$ rRNA of lupin (10000 c.p.m.) in buffer 3; 2-7, TFIIIA to $5 S$ rRNA ratio 20:1, 30:1, 50:1, 100:1, 200:1 and 300:1, respectively in the presence of RNasin; 8-10, TFIIIA to 5S rRNA ratio 100:1, 200:1 and 300:1, respectively in buffer 3 without Nonidet $P-40 ; 11-13$, the same as in 8-10 but in buffer 3 without $\mathrm{Zn}^{2+}$ ions; $14-16$, the same as $8-10$ but in buffer 3 without glycerol ( $5 \mathrm{~S}$ rRNA — triangle, 7S RNP - arrow). 


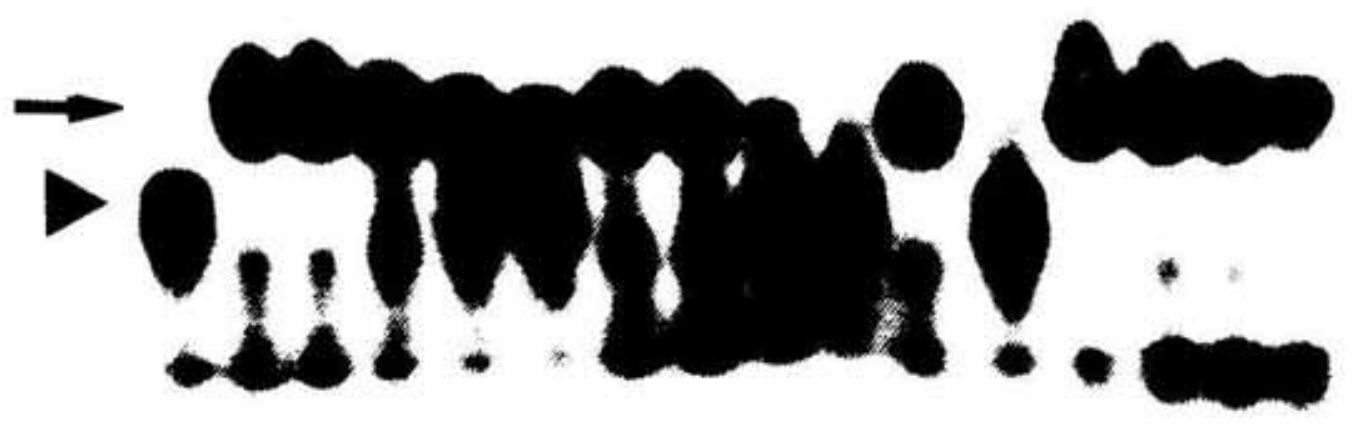

\section{$\begin{array}{llllllllllll}12 & 3 & 4 & 5 & 6 & 7 & 8 & 9 & 11 & 13 & 15\end{array}$ \\ $\begin{array}{llll}10 & 12 & 14 & 16\end{array}$}

Fig. 5. The effects of $\mathrm{Mg}^{2+}, \mathrm{K}^{+}$and $\mathrm{Zn}^{2+}$ ions and EDTA and DTT on binding of lupin 5S rRNA with Xenopus TFIIIA in buffer 3 with 1 mmole of TFIIIA and 1 nmole ${ }^{32}$ P-labeled-5S rRNA (10000 c.p.m.).

Lanes: 1,5SrRNA; 2, complex without magnesium;3-6, complex in the presence of $0.1,1,2$ and 5 mM magnesium; 7-10, $50,100,200$ and $300 \mathrm{mM} \mathrm{KCl} ; 11-12,0.01$ and $0.1 \mathrm{mM}$ zinc; $13-14,0,1$ and $1 \mathrm{mM}$ EDTA; $15-16,0.1 \mathrm{M}$ and $0.2 \mathrm{mM}$ DTT (5S rRNA - triangle, 7S RNP - arrow).

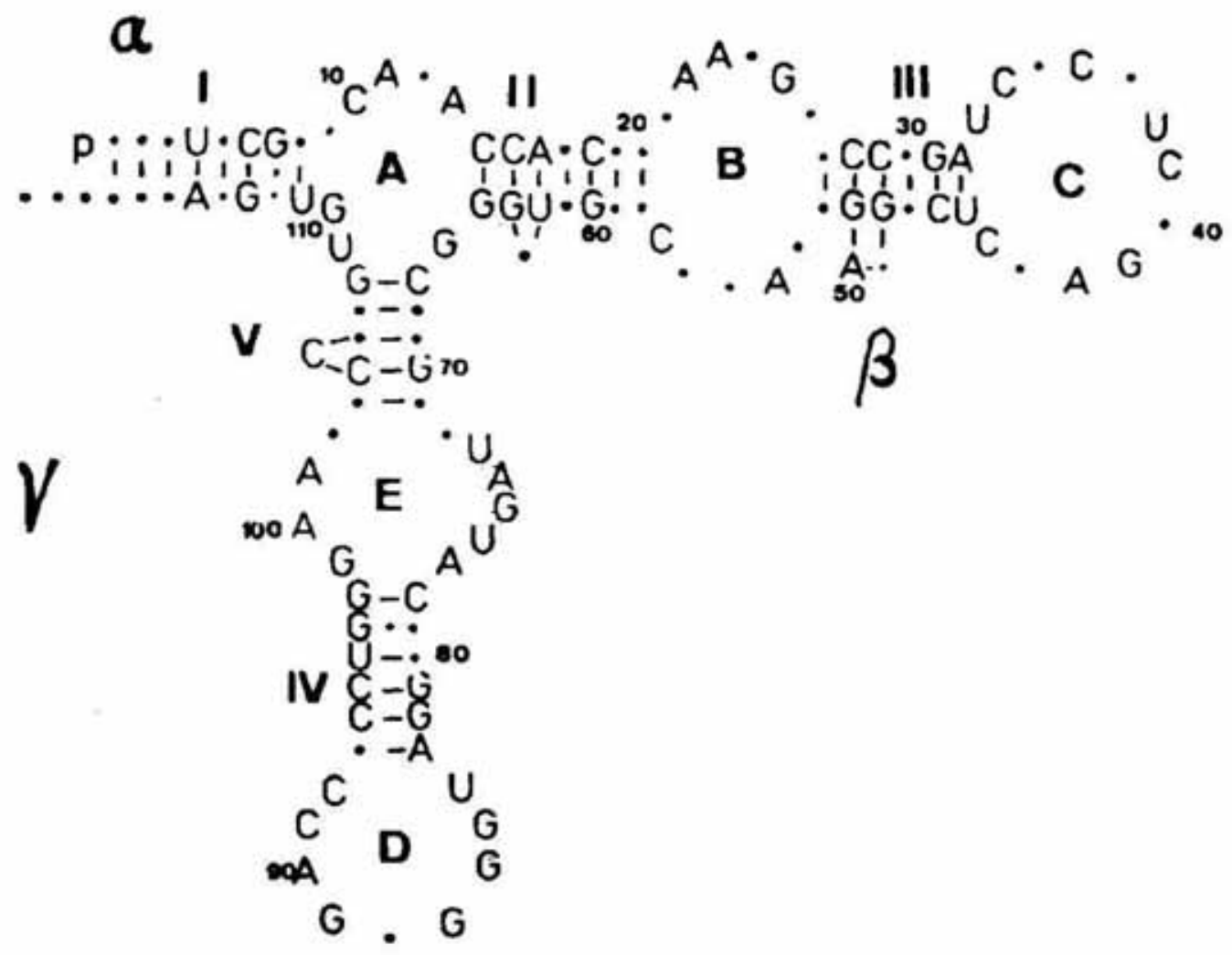

Fig. 6. The secondary structure of plant $5 S r R N A$ (lupin, wheat) and Xenopus $5 S r R N A$ recognized by the Xenopus transcriptional factor IIIA; the conserved nucleotides are shown not only in the region between nucleotides 66 and 110 but throughout the whole molecule. 
tained at a 1:1 ratio of the reactants (Figs. 3 and 5). It seems that the divalent cations $\left(\mathrm{Zn}^{2+}\right.$ and $\mathrm{Mg}^{2+}$ ) play a crucial role in the protein-ribonucleic acids recognition mechanism. It is know that $\mathrm{Zn}^{2+}$ ions are necessary to stabilize some structural domains in TFIIIA [27]. From the differential scanning calorimetry studies I know that the conformation of plant $5 S$ rRNAs is changed at magnesium concentration of about $2 \mathrm{mM}$ [30]. Therefore it is reasonable to suppose that the 5S rRNA conformer is not recognized by the Xenopus TFIIIA in the presence of higher magnesium concentration. The main conclusion of this work is that the cognate $5 \mathrm{~S}$ rRNA as well as plant $5 \mathrm{~S}$ rRNAs are efficiently recognized by Xenopus TFIIIA. I compared the nucleotide sequences of all the $5 \mathrm{~S}$ rRNAs studied (Table 1,Fig. 6) and noticed that despite marked differences in their primary structures, there is a remarkable similarity between their higher order structures. The highest conservation of the nucleotides occurs in stems IV and V and loops D and E (domain $\gamma$ [7]). It seems that this part of $5 \mathrm{~S}$ rRNA is crucial for the interaction within the transcriptional complex. The consensus nucleotide sequence (Fig. 6) is similar to the results obtained for the truncated Xenopus 5S rRNA [26]. However, there are some differences between the two structures. From the filter binding experiments [15] it is known that the affinity with which Xenopus TFIIIA binds wheat $5 \mathrm{~S}$ rRNA is twice as high as that of binding Xenopus 55 rRNA, where as in the case of $E$. coli $5 S$ rRNA it is one-fourth of the latter [15]. From comparison of those data with the free energy calculation [29] (Table 1) one can see that the 5S rRNA with the highest affinity for TFIIIA has at the same time the lowest free energy. Therefore I conclude that there is a correlation between strength of RNA binding and the free energy of the RNA calculated with the Zuker programme $[28,29]$. These data suggest that the two eukaryotic $5 \mathrm{~S}$ rRNAs studied have a similar tertiary structure, notwithstanding that for either a different structural model has been proposed [ 4 , $7,19,20,28]$.

M.Z.B. received an EMBO short term fellowship to visit MRC Cambridge, England during the course of this work and thanks Dr. Daniela Rhodes for gift of pure 7S RNP and critical comments on the manuscript.

\section{REFERENCES}

1. Fairall, L., Rhodes, D. \& Klug, A. (1986) Mapping of the sites of protection on 5S RNA gene by the Xenopus transcription factor IIIA. J. Mol. Biol. 192, 577-591.

2. Klug, A. \& Rhodes, D. (1987) Zinc fingers: a novel protein motif for nucleic acid recognition. Trends Biochem. Sci. 12, 464-469.

3. Romaniuk, P.J., Leal de Stevenson, I., Ehresmann, C., Romby, P. \& Ehresmann, B. (1988) A comparison of the solution structures and conformational properties of the somatic and oocyte 5S rRNAs of Xenopus laevis. Nucl. Acids Res. 16, 2295-2312.

4. Romby, P., Baudin, F., Brunel, C., Leal de Stevenson, I., Westhof, E., Romaniuk, P.J., Ehreshmann, C. \& Ehresmann, B. (1990) Ribosomal 5S rRNA from Xenopus laevis: conformation and interaction with transcription factor IIIA. Biochemie 72, 437-452.

5. You, Q., Veldhoen, N., Baudin, F. \& Romaniuk, P. (1991) Mutations in 5S DNA and 5S RNA have different effects on the binding of Xenopus transcription factor IIIA. Biochemistry 30 , 2495-2500.

6. Baudin, F., Romaniuk, P.J., Romby, P., Brunel, C., Westhof, E., Ehresmann, E. \& Ehresmann, C. (1991) Involvement of hinge nucleotides of Xenopus laevis of $5 \mathrm{~S}$ rRNA in RNA structural organisation and in the binding of TFIIIA. J. Mol. Biol. 218, 69-81.

7. Joachimiak, A., Nalaskowska, M., Barciszewska, M., Mashkova, T.D. \& Barciszewski, J. (1990) Higher plant $5 S$ rRNAs share common secondary and tertiary structure. A new three dimensional model. Int. J. Biol. Macromol. 12, 321-327.

8. Pelham, H.R.B. \& Brown, D.D. (1980) A specific transcription factor that can bind either the 55 RNA gene or 5S RNA. Proc. Natl. Acad. Sci. U.S.A. 76, 241-245.

9. Guddat, U., Bakken, A.H. \& Pieler, T. (1990) Protein-mediated nuclear export of RNA: 5S rRNA containing small RNP in Xenopus oocytes. Cell 60, 619-628.

10. Berg, J.M. (1988) Proposed structure for the zinc-binding domains from transcription factor IIIA and related proteins. Proc. Natl. Acad. Sci. U.S.A. 85, 99-102.

11. Engelke, D.R. \& Gottesfeld, J.M. (1990) Chromosomal footprinting of transcriptionally active 
and inactive oocyte type 5S rRNA genes of $X$. laevis. Nucl. Acids Res. 18, 6031-6037.

12. Fairall, L., Martin, S. \& Rhodes, D. (1989) The DNA binding site of the Xenopus transcription factor IIIA has a non-B-form structure. $E M B O J$. 8, 1809-1817.

13. Miller, J., Mc Lachlan, A.D. \& Klug, A. (1985) Repetitive zinc-binding domains in the protein transcription factor IIIA from Xenopus oocytes. EMBO J. 4, 1609-1614.

14. Wolffe, A.P., Jordan, E. \& Brown, D.D. (1986) A bacteriophage RNA polymerase transcribed through Xenopus 5S RNA gene transcription complex without it. Cell 44, 381-389.

15. Romaniuk, P.J. (1985) Characterisation of the RNA binding properties of transcription factor IIIA from Xenopus laevis oocytes. Nucl. Acids Res. 13, 5369-5387.

16. You, Q., Veldhoen, N., Baudin, F. \& Romaniuk, PJ. (1991) Mutations in 5S DNA and 5S RNA have different effects on the binding of Xenopus transcription factor IIIA. Biochemistry 30, 2495-2500.

17. Honda, B. \& Roeder, R. (1990) Association of a 5S rRNA gene transcription factor with 5S RNA and altered levels of the factor during cell differentiation. Cell 22, 114-126.

18. Romaniuk, P.J. (1989) The role of highly conserved single stranded nucleotides of Xenopus 5S rRNA. Biochemistry 28, 1388-1395.

19. Westhof, E., Romby, P., Romaniuk, P.J., Ebel, J.P., Ehresmann, C. \& Ehresmann, B. (1989) Computer modeling from solution data spinach chloro- plast and Xenopus laevis somatic and oocyte 5S rRNA. J. Mol. Biol. 207, 417-431.

20. Christiansen, J., Brown, R.S., Sproat, B.S. \& Garrett, R.A. (1987) Xenopus transcription factor IIIA binds primarily at functions between double helical stems and internal loops in oocyte 5S rRNA. EMBO J. 6, 453-460.

21. Pieler, T., Erdmann, V.A. \& Appel, B. (1984) Structural requirements for the interaction of $5 \mathrm{~S}$ rRNA with the eucaryotic factor IIIA. Nucl. Acids Res. 12, 8393-8406.

22. Andersen, J. \& Delihas, N. (1986) Characterisation of RNA-protein interactions in $7 \mathrm{~S}$ ribonucleo- protein particles from Xenopus laevis. J. Biol. Chem. 261, 2912-2917.

23. Barciszewska, M., Lorentz, S., Endmann, V.A. \& Barciszewski, J. (1990) Structural analysis of plant ribosomal 5S rRNAs. Visualisation of novel tertiary interactions by cleavage of lupin and wheat $5 \mathrm{~S}$ rRNAs with RNase H. Biochim. Biophys. Acta 1087, 68-72.
24. Barciszewska, M., Huang, H.-W., Marshall, A.G., Endmann, V.A. \& Barciszewski, J. (1992) Biochemical and NMR spectroscopy evidence for a new tertiary A-U base pair in lupin ribosomal 5S RNA. J. Biol. Chem. 267, 16691-16695.

25. Miller, J., Fairall, L. \& Rhodes, D. (1989) A novel method for the purification of the Xenopus transcriptional factor IIIA. Nucl. Acids Res. 17, 9185-9182.

26. Romaniuk, P.J., Leal de Stevenson, I. \& Wong, A. (1987) Defining the binding site of Xenopus transcriptional factor IIIA on 5S RNA using truncated and chimeric 5S rRNA molecules. Nucl. Acids Res. 15, 2737-2755.

27. Bogenhagen, D.F. (1985) The intragenic control region of the Xenopus 5S rRNA gene contains two factor $\mathrm{A}$ binding domains that must be aligned properly for efficient transcription initiation. J. Biol. Chem. 260, 6466-6471.

28. Mashkova, T.D., Barciszewska, M., Joachimiak, A., Nalaskowska, M. \& Barciszewski, J. (1990) Molecular evolution of plants as deduced from changes in free energy of $5 S$ ribosomal RNAs. Int. J. Biol. Macromol. 12, 247-250.

29. Joachimiak, A., Basavappa, R., Banciszewska, M.Z., Nalaskowska, M. \& Barciszewski, J. (1990) Tertiary structure and modeling of plant ribosomal 5S RNA. Acta Biochim. Polon. 37, 359-375.

30. Barciszewski, J., Bratek-Wiewiórowska, M.D., Górnicki, P., Naskrett-Barciszewska, M., Wiewiórowski, M., Zielenkiewicz, A. \& Zielenkiewicz, W. (1988) Comparative calorimetric studies on the dynamic conformation of plant $5 S$ rRNAs. I. Thermal unfolding pattern of lupin seeds and wheat germ $5 S$ rRNAs, also in presence of magnesium and sperminum cations. Nucl. Acids Res. 16, 685-695. 